ELORE (ISSN 1456-3010), vol. $14-1 / 2007$.

Julkaisija: Suomen Kansantietouden Tutkijain Seura ry.

[http://www.elore.fi/arkisto/1_07/fin_b_1_07.pdf]

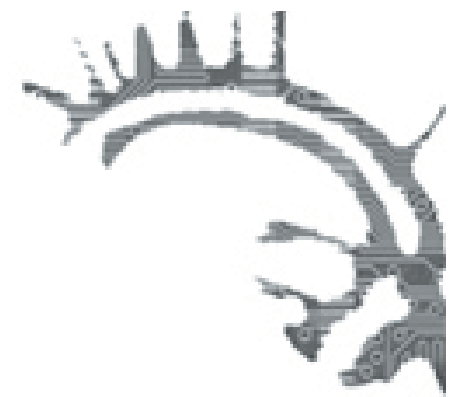

\title{
KIRJA-ARVIO: \\ VEPSÄLÄISTEN NAISTEN USKONTO VOI HYVIN 1990-LUVUN VENÄJÄLLÄ
}

\author{
Heikkinen, Kaija 2006: Metsänpelko ja tietäjänaiset. Suomalaisen Kirjallisuu- \\ den Seuran Toimituksia 1081. Helsinki: Suomalaisen Kirjallisuuden Seura. 276 \\ sivua.
}

\section{$\underline{\text { Outi Fingerroos }}$}

Kaija Heikkinen on Joensuun yliopiston naistutkimuksen professori ja taustaltaan monialainen kulttuurien tutkija. Heikkisen kirjoittama Metsänpelko ja tietäjänaiset on kirja vepsäläisten etnisestä uskonnosta 1990-luvun Venäjällä. Tutkijan näkökulmana on vepsäläisnaisten luontosuhde ja sukupuolittunut henkinen johtajuus erilaisissa uskonnollisissa tilanteissa. Kirja yhdistääkin kiinnostavalla tavalla näkökulmia uskontotieteestä, naistutkimuksesta ja ylipäätään kulttuurien tutkimuksesta.

Kirja on syntynyt Kaija Heikkisen pitkäaikaisen tutkijantyön tuloksena. Tutkimusaiheeseensa Heikkinen vihkiytyi 1980-luvun lopussa, jolloin hän inspiroitui valokuvasta, joka esitti vepsäläisnaisia suorittamassa "oudontuntuisia menoja metsässä” (s. 13). Heikkinen vieraili ensimmäisen kerran vepsäläiskylissä pian tämän jälkeen vuonna 1991: aikana, jolloin perestroika mahdollisti kansainvälisen tutkimuksen. Luinkin kiinnostuneena kirjan esipuheesta, miten neuvostoajan päättyminen vaikutti paitsi suomalais-ugrilaisten kansojen elämään myös tutkimuksentekoon. Rajan taakse nimittäin lähdettiiin valtavalla innolla. Tällöin käynnistyivät muiden muassa Anna-Leena Siikalan uralilaisten kansojen mytologiaa ja Risto Alapuron kansalaisyhteiskuntien kehittymistä käsittelevät hankkeet. Molemmilla hankkeilla oli yhteys Joensuun yliopiston Karjalan tutkimuslaitokseen, jossa Heikkinen työskenteli 1990-luvulla tutkijana. Heikkiselle kontaktit Petroskoihin ovat olleet merkittäviä, ja hän muistaakin kiittää esipuheessa kanssatutkijoitaan monin eri tavoin.

Rajan taakse lähteneiden tutkijoiden itsensäkin on ollut jälkikäteen vaikea ymmärtää omaa kiihkoaan ja innostustaan. Perestroikan synnyttämien tunteiden ja 
kenttäkokemusten refleksio alkaakin olla itsenäinen tutkimuskysymys. Tästä puolesta Vepsää olisin mielelläni lukenut Heikkisen kirjoittamana lisää, sillä kyse on uudesta ja mielenkiintoisesta oppihistoriasta.

\section{VEPSÄLÄISNAISILLA ON ERITYINEN SUHDE USKONTOON JA LUONTOON}

Perestroikasta ja rajojen aukeamisesta huolimatta yksi on Vepsässä säilynyt: syrjäisten maaseutukylien sosiaaliset, taloudelliset ja uskonnolliset olot. Lisäksi Vepsään liitetään edelleen sana metsä. Heikkinen hakee inspiraationsa 1990-luvun Keski-Vepsän pienistä kylistä. Hän määrittää tutkimustehtäväkseen kyläluonnon ja villin luonnon välisen vastakkaisuuden selvittämisen ja on kiinnostunut vaaroista; tarkastelu kohdentuu tutun ja tuntemattoman väliseen rajanylitykseen sukupuolittuneesti. Metsänpelko ja tietäjänaiset alkaakin Heikkisen taitavasti rakentamalla etnografisella kuvauksella miikkulanpäivän juhlasta:

Juhlissa hämmästytti niiden vaatimattomuus, naisten keskinäinen yhteistoiminta, rituaalinen yksinkertaisuus ja intensiivinen henkinen lataus. Myös sulautuminen luontoon - oltiin lähellä peltoa ja vettä - loi vahvan tunnelman. Voimakas yhteisöllisyyden tunnelma leimasi tilaisuutta. Miehiä ei näkynyt. Naiset hoitivat menot itse. (s. 14.)

Alun etnografisen kuvauksen avulla lukija pääsee kiinni kirjan juoneen, sillä Heikkinen esittelee seitsemässä luvussa vepsäläisten naisten rituaalielämän koko kirjon. Käsittelyssä saavat sijansa muiden muassa lupausjuhlat ja kyläpraasniekat, erilaiset uhrit ja jumalten lahjat, ristiveden pyhittäminen ja siinä kylpeminen, tsasounissa harjoitettava uskonnollisuus, metsän vaarojen torjunta ja tietäjänaisten toimet. Kirjan juoni rytmittyy myös kontekstin tarkastelun avulla, sillä Heikkinen pohtii kautta linjan naisten harjoittaman kansanuskon ja kristinuskon suhteita. Esimerkiksi haltijausko oli vepsäläisten keskuudessa 1990-luvulla yleistä, mihin lienee vaikuttanut se, että vallankumouksen jälkeisinä vuosina kansanusko sai uusia sisältöjä: kristinuskoa pidettiin pinnallisempana ja nopeammin ohimenevänä ilmiönä kuin vepsäläisten harjoittamaa etnistä uskontoa. Uhrijuhlat taas ovat mielenkiintoinen sekoitus kristillisiä aineksia, magiaa ja muuta rituaalikulttuuria, jota hallitsevat "vanhat naiset". Metsänhaltijaa lepyttelevä tietäjänainen saattaakin toimia myös vedenvihkimisen suorittavana pappinaisena. Lauri Honko $(1978,89)$ on nimittänyt tällaisia rituaalielämän spesialisteja psykopompoksiksi (1).

Uskonnosta muodostuu tutkimukselle avainkäsite, jota Heikkinen määrittelee uskontotieteilijä Susan Seredin (1994) lanseeraaman "uskonnon tiheän sukupuolittuneisuuden" teeman avulla. Näin uskontotieteessäkin vaikeasti määriteltävä käsite lähtee liikkeelle ja saa sellaisia sisältöjä kuin naisten uskonto tai naisten dominoima uskonto (alkup. female-dominated religion). Tällaiselle uskonnolle on ominaista naisten henkinen johtajuus ja osallistuminen uskonnollisiksi luonnehdittaviin menoihin (s. 21). 


\section{OUtI FingerRoOS}

Vepsäläistä kontekstia Heikkinen luonnehtii ateistiseksi, mikä asettaa naisten uskonnollisuuden tarkastelun haasteen eteen: "Tällöin on kysyttävä, antoiko hyväksytyn uskonnon puuttuminen jotain erityistä naisten harjoittamalle uskonnolle?" ja "Voiko vepsäläisnaisten uskonnollinen ja rituaalinen kulttuuri tuoda jotakin uutta uskonnon sukupuolittuneisuuden tarkasteluun?” (s. 23.)

Se, mitä jäin käsittelyltä uskontotieteilijänä kaipaamaan, oli sukupuolittuneen uskontotieteellisen rituaaliteorian käsittely edes yleisellä tasolla. Esimerkiksi Aili Nenola on kirjoittanut miesten ja naisten rituaalisesta käyttäytymisestä sekä suuren ja pienen tradition välisestä erosta useammassakin artikkelissaan (esim. Nenola 1981; 1983; 1985; 1990). Heikkinen kuitenkin näyttää tiedostavan tämän ongelman, sillä hän osoittaa (s. 231-232 Serediin 1994 viitaten), että aiemmassa tutkimuksessa on ollut tapana korostaa naisten uskonnollisuutta niin, että se asetetaan miehiseksi ymmärrettyä teologista uskontoa vasten. Vepsäläisnaisten harjoittamalle uskonnolle on ominaista luonnon rituaalinen manipulointi, jota motivoi huoli yhteisön hyvinvoinnista. Rituaalien avulla naiset siis hallitsevat luonnosta tulevia vaaroja, ja heillä on selkeä paikka vepsäläisessä kyläyhteisössä.

Tutkimuksen toinen avainkäsite on vepsäläisnaisten luontosubde, jonka Heikkinen määrittelee konkreettisiksi luontoon suhtautumisen tavoiksi ja näkökulmiksi; käsitteellä on siten yhteys myös olemassaolon eksistenssiin (s. 20). Ympäristösuhteesta vepsäläisnaisten kohdalla ei mielestäni voi edes puhua, sillä Heikkisen työssään kuvaamat rituaalit ilmentävät luontosuhdetta ja naisten aktiivista toimintaa yhteisössään. Tällaiseen luontosuhteeseen ei sisälly sen enempää luontoon alistumista kuin hallintaakaan. Esimerkiksi voi nostaa luvun "Metsä ihmisten käytössä", jossa käsitellään muiden muassa jokakesäisiä lupausjuhlia laidunonnen takaamiseksi. Vepsäläiset nimittäin ajattelevat kevään jakavan maailman kahteen osaan, metsässä alkavaan paimenen aikaan (paimenen aig) ja sinne päättyvään vieraaseen aikaan (vieras aig). Paimen on metsässä kulkija, jonka pitää lunastaa kulkulupa solmimalla metsän haltijan kanssa erilaisia sopimuksia. Paimenet erottuvatkin muista kyläläisistä tietäjien ryhmäksi, jonka yläpuolelle asettuvat vain arvostetut tietäjänaiset: ne, joilla on kyky suojata karja ja jotka viime kädessä hoitavat myös yhteydenpidon metsänhaltijaan.

Paikoin Heikkisen käsittelyssä vilahtaa myös käsite magia, jota hän ei alun luvuissa tarkemmin määrittele. Magia-käsitteen käyttö on tutkimuksessa kuitenkin perusteltua, sillä Heikkinen osoittaa, miten periaatteiltaan ateistinen yhteiskunta siirsi monet rituaalit syrjään puolijulkisen uskonnon ja magian alueelle. Esimerkeiksi tällaisista rituaaleista sopivat lupausjuhlat ja vedenpyhitys, jotka suoritti ennen neuvostoaikaa pappi, sittemmin maallikkonainen. Samaan tapaan rukous- ja uhrijuhlat siirtyivät piiloon vepsäläisiin koteihin.

\section{KinNostaVAa PUHETTA HEIMOAJATTELUSTA}

Vepsä on suomalaisille kaukainen, vaikka heimoajattelu onkin sitonut suomalaiset, karjalaiset ja vepsäläiset tiukasti yhteen. Heikkinen teki kansatieteellisessä väitöskir- 
jassaan Karjalaisuus ja etninen itsetajunta (1989) tarpeellisen avauksen kriittiseen Karjalatutkimukseen toteamalla, että paikasta kertovissa lähteissä on epämääräisiä käsityksiä siitä, mikä Karjala edes on. Vienasta muodostui koko Karjalan mallialue, joka mielikuva yleistyi ja alkoi vähitellen edustaa koko karjalaista kulttuuria. (Heikkinen 1989, 16-21.) Samanlaista pohdintaa Heikkinen käy uudessa tutkimuksessaan Vepsästä:

Vepsäläisiä on tutkittu paljon vähemmän [OF: kuin karjalaisia], mihin on useita syitä. Vepsäläisiltä on puuttunut kalevalamittainen eeppinen runous, jota suomalaiset ovat pitäneet 1800-luvun kansallisuusliikkeen ajoista lähtien folkloren aarteena. (s. 47.)

Heikkisen kaltaiselle tutkijalle Vepsä siis on vähän samanlainen löytö kuin kriittiselle uskontotieteilijälle luterilainen Kannas (ks. Fingerroos 2004) tai nykyetnologille saamelaisalueen ulkopuolelle jäävä "rajamaa" (Ruotsala 2002). Vepsä on kuitenkin hyvin erilainen kuin Karjala tai Lappi: Vepsäläisiä ei käytetty Suomen valtion rakentamiseen. Vepsäläisten neuvostovallan aikainen kansallinen "olemattomuus" ei sekään ollut suotuisa lähtökohta tutkimukselle. Venäjän vähemmistökansallisuuksien kulttuuriliikehdintä on kuitenkin elvyttänyt vepsän kielen ja kulttuurin tutkimusta 1990-luvulla, mihin kontekstiin Heikkinen sijoittaa tutkimuksen lopussa myös itsensä:

Vepsäläisyyden korostaminen johtaa uudestaan tutkimustyön lähtökohtiin. Olen yhdeltä osin mukana vepsäläisliikkeessä. Tämä intressi selittää osaltaan haastattelutilanteiden intiimin etnisen luonteen. Voidaan sanoa, että kylän naiset puhuessaan meidän ja toistensa kanssa tuottavat jälkisosialistista vepsäläisyyttä, joka realisoituu rituaalikulttuurina ja uskontona. Tämä kaikki tapahtuu aivan erityisessä naiseuden kontekstissa. (s. 249.)

\section{KIRJA ON TARPEELLINEN LISÄ KANSANUSKOA KÄSITTELEVÄLLE TUTKIMUKSELLE}

Olen itse opettanut vuosia uskontotieteen perusopinnoissa "Uskonnollisuus Suomessa" -kurssia ja pitänyt kansanuskosta teemaseminaareja. Opettajalle ja tutkintorakenteen suunnittelijalle kansanuskoa käsittelevät perusopintotasoiset kurssit ovat ongelma, koska kotimaista kirjallisuutta aiheesta on kovin vähän. Esimerkiksi Turussa uskontotieteilijät tenttivät Anna-Leena Siikalan Suomalaisen šamanismin (1992); kansainväliselle kentälle mentäessä tarjonta taas pirstaloituu liikaa. Varsinaisesti Metsänpelko ja tietäjänaisetkaan ei poista ongelmaa, mutta kirja on kuitenkin kelpo lisä jopa kurssitarjottimeen. Ainakin se tarjoaa opettajalle paljon virikkeitä ja ideoita. Oikeastaan olen sitä mieltä, että Heikkisen kannattaisi kirjoittaa vepsäläisten uskonnosta vielä toinenkin kirja: sellainen, joka olisi nimenomaan kansanuskoa nykymuodoissaan käsittelevä yliopistollinen oppikirja. Erillistä artikkelia jään kaipaamaan Vepsään suuntautuneen kenttätyön refleksiosta. 


\section{OUtI FingerRoOS}

Suomalaisen Kirjallisuuden Seuran kustantamalla kirjalla on kaunis ulkoasu ja taitto, ja kuvat ovat Mikko Savolaisen takuuvarmaa jälkeä. Valitettavaa vain on, että kuvien laatu jää jälleen heikoksi - niin kuin se monesti on viime aikoina jäänyt esimerkiksi Kalevalaseuran vuosikirjoissa ja Suomalaisen Kirjallisuuden Seuran Toimituksia -sarjassa. Paikoitellen kustannustoimittajan kädenjälkeä olisi tarvittu myös tekstien viimeistelyssä - ei sen vuoksi, että Heikkinen ei osaisi kirjoittaa hyvin, vaan kirjan populaarimmankin luettavuuden vuoksi. Nämä muotoseikat ovat kuitenkin asioita, joihin Kaija Heikkinen ja Mikko Savolainen eivät ole voineet vaikuttaa. Metsänpelko ja tietäjänaiset -kirjalle vain olisi suonut viimeistellymmän muodon ja kovat kannet, sillä se todellakin on tarpeellinen lisä kansanuskoa käsittelevään suomenkieliseen tutkimuskirjallisuuteen.

\section{VIITTEET}

1. Lauri Hongon mukaan itkuvirsien esittäjä toimii yhteisössään psykologisena ohjaajana tai sielun johdattelijana - "as psychopomp". Ks. Honko 1978, 89.

\section{KirjallisuUs}

FINGERROOS, OUTI 2004: Haudatut muistot. Rituaalisen kuoleman merkitykset Karjalankannaksella. Suomalaisen Kirjallisuuden Seuran Toimituksia 985. Helsinki: Suomalaisen Kirjallisuuden Seura.

HEIKKINEN, KAIJA 1989: Karjalaisuus ja etninen itsetajunta. Salmin siirtokarjalaisia koskeva tutkimus. Joensuun yliopiston humanistisia julkaisuja N:o 9. Joensuu: Joensuun yliopisto.

HONKO, LAURI 1978: The Ingrian Lamenter as Psychopomp. - Temenos 14: 79-96.

NENOLA(-KALLIO), AILI 1981: Kuolema naisten maailmankuvassa. - Suomen antropologi 6: 4-28.

- 1983: Itkukiellot ja naisten kulttuuri. - Kotisentu 74(1): 7-10.

— 1985: Kuolema, yksilö ja yhteisö. Kuolemanrituaalien alustavaa tarkastelua. - Junnonaho, Martti (toim.), Folkloristiikeka ja uskontotiedettä. Etiäinen 1. Turku: Turun yliopisto, kulttuurien tutkimuksen laitos.

— 1990: Kuolema kohtaa naisen. - Aromaa, Vuokko et al. (toim.), Naisen elämä. Mistä on pienet tytöt tehty, mistä tyttöjen äidit. Helsinki: Kustannusosakeyhtiö Otava.

RUOTSALA, HELENA 2002: Munttwat palkiset. Elo, työ ja ympäristö Kittilän Kyrön paliskunnassa ja Kuolan Lumjärven poronhoitokollektiivissa vuosina 1930-1995. Kansatieteellinen Arkisto 49. Helsinki: Suomen Muinaismuistoyhdistys. 
VEPSÄLÄISTEN NAISTEN USKONTO VOI HYVIN 1990-LUVUN VENÄJÄLLÄ

SERED, SUSAN 1994: Priestess, Mothers, Sacred Sisters. Religions Dominated by Women. New York: Oxford University Press.

SIIKALA, ANNA-LEENA 1992. Suomalainen šamanismi - mielikuvien historiaa. Suomalaisen Kirjallisuuden Seuran Toimituksia 565. Helsinki: Suomalaisen Kirjallisuuden Seura.

FT Outi Fingerroos on Suomen Akatemian tutkijatohtori ja uskontotieteilijä Turun yliopiston kulttuurien tutkimuksen laitoksessa. 